\title{
Petrophysical Evaluation of the Sarvak Formation Based on Well Logs in Dezful Embayment, Zagros Fold Zone, South West of Iran
}

\author{
Akram Jooybari \\ Geology Department \\ University of Hormozgan \\ Bandar Abbas, Iran \\ a91.jooybari@gmail.com
}

\author{
Peiman Rezaie \\ Geology Department \\ Hormozgan University \\ Bandar Abbas, Iran \\ peiman_rezaie@yahoo.com
}

\begin{abstract}
Dezful embayment in the south west of Iran is part of Zagros fold zone which despite the small area includes almost all of Iran oil production. Sarvak Formation with middle cretaceous (Albin-Turunin) is the second biggest reservoir of Zagros basin, after the Asmari formation. In this study, with well logging data of two wells, by Geolog software, the petrophysical parameters of Sarvak Formation in the Dezful embayment was studied using the contingent Probabilistic method. Petrophysical parameters such as determination of porosity, water saturation, shale volume and lithology were calculated using this data and common cross plots. Based on this evaluation and utilizing cross plots result, the lithology of Sarvak formation in this zone was determined to be Limestone with traces of dolomite and shale. According to the calculated petrophysical properties of the reservoir, and for more accurate assessment, Sarvak Formation was divided to 6 sections. Findings of this research show that Sarvak Formation includes good reservoir parameters only in half its sections (sections 4, 2 and 6).
\end{abstract}

Keywords-Petrophysical evaluation; Dezful embayment; Sarvak Formation; Iran

\section{INTRODUCTION}

The Bangestan Group of Albian-Campanian age contains some of the most prolific reservoirs of the Arabian Plate and Zagros Basin hydrocarbon provinces, predominantly within neritic carbonates of the Sarvak Formation and equivalent units (e.g., the Mishrif Formation in Iraq). Dezful embayment (southwest of Iran) is one most important hydrocarbon states in world which located in northeast of Arabian plate margin [1]. Petrophysical evaluation is the science of insight and interpretation of obtained information from well logging for examination of the reservoir quality of different parts of formation and for determining the best zones for optimized exploitation of reservoirs and development of oil fields [2]. Recognition of lithology, calculating the shale volume, porosity and water saturation are the most important parameters in petrophysical evaluation necessary to determine a reservoir's quality [3]. The aim of this study is to specify the reservoir's parameters and evaluate the quality of Sarvak Formation in the Dezful embayment. In this study well logging data from two wells (A and B) in Sarvak Formation and Geolog software have been used to determine petrophysical parameters. Similar studies have been performed in different regions [4-7]. Also, in [8], this approach has been combined with other techniques to study the Mishrif Formation in Iraq, which is equivalent to the Sarvak Formation.

\section{GEOLOGICAL SETTING}

More than $65 \%$ of confirmed petroleum resources in the world and $34 \%$ of gas fields in the world are located in giant hydrocarbonic fields in the Middle East [9]. The Zagros fold and thrust belt is one of the most important active tectonics belts in the Middle East, that is in south-west of Iran between the Arabian Plate and the center of Iran [10]. The belt is extended along the north-northwest boundary of Arabian Plate, i.e. from the southeast of Turkey, Syria and Iraq to the Minab's fault in the south of Iran [11]. This area includes enormous hydrocarbonic fields and consequently it is distinguished as one of the richest oil belts in the world [12]. Dezfol embayment in Zagros is surrounded by three important structural features which are: the Flexural Balarood zone in the northwest, the mountain bend front in the northeast and a complicated fault zone named Qatar-Kazerun in the east and southeast (Figure 1). Zagros Mountains width consists of major anticlines, elevated and folded, which contain several reservoir inside [13]. More than 45 perineum fields have been discovered inside the Dezfol embayment [14]. The Dezful embayment zone despite the small area (about $40000 \mathrm{~km}^{2}$ ), includes almost all of Iran's oil production [14]. Oil reservoirs in this zone include the Khami group (Fahlian and Daraian Formations) and the Bangestan group (Ilam and Sarvak Formations) and the Asmari reservoir. Thick sedimentary successions of Cretaceous age in the Arabian Plate and Zagros Basin contain numerous economically important hydrocarbon accumulations [15-20]. The development of an epeiric platform occurred during the Early Cretaceous throughout the Middle East $[21,22]$. The 
stratigraphic record of the Late Albian, Cenomanian and Turonian (89-98.9 Ma) in the Arabian Plate and Zagros Basin includes the Mishrif, Ahmadi and Rumaila Formations in Saudi Arabia, the Natih Formation in Oman [23, 24], the Derdere Formation in south-east Turkey, the Mishrif Formation in Iraq and the Sarvak Formation (Figure 2). The Sarvak Formation middle cretaceous (Albin-Turunin) is in the Bangestan group. The upper boundary of the Sarvak Formation is discontinuous with part of Ilam Formation deposited on it whereas the lower boundary is transitional boundary with the Kazhdumi Formation (Figure 2A). Lithology of these formations are mainly limestone and dolomite in some parts. Sarvak Formation includes two facies, shallow and deep. The lower part of Sarvak Formation includes clay limestone and pelagic and the reservoir quality is lower than in the upper part of formation. The upper part of Sarvak formation shows higher reservoir quality which can be attributed to effect of discontinuity between the two parts [25-28]. This formation is widely present in the Dezful embayment and the Persian Gulf [29]. Many studies have focused on the Sarvak Formation which, in a qualitative sense, has become known as the second biggest reservoir of Iran [18, 25-27, 30-31].

\section{DATA AND METHODOLOGY}

In this study, well logging data from two well were used. Raw and environmental data were provided. These data were digitized by Surfer 9 software and conversed with a proper format (LAS) for Geololg software. Depth matching was performed before quantity processing. Notron and Density logs were used as the basis for matching logs. Next, environment correction is performed by Schlumberger standard charts on the whole logs. In the next stage the Multimin method was used in Geolog for calculations. Finally, data is surveyed and evaluated, the necessary parameters are calculated and petrophical crossplots are acquired.

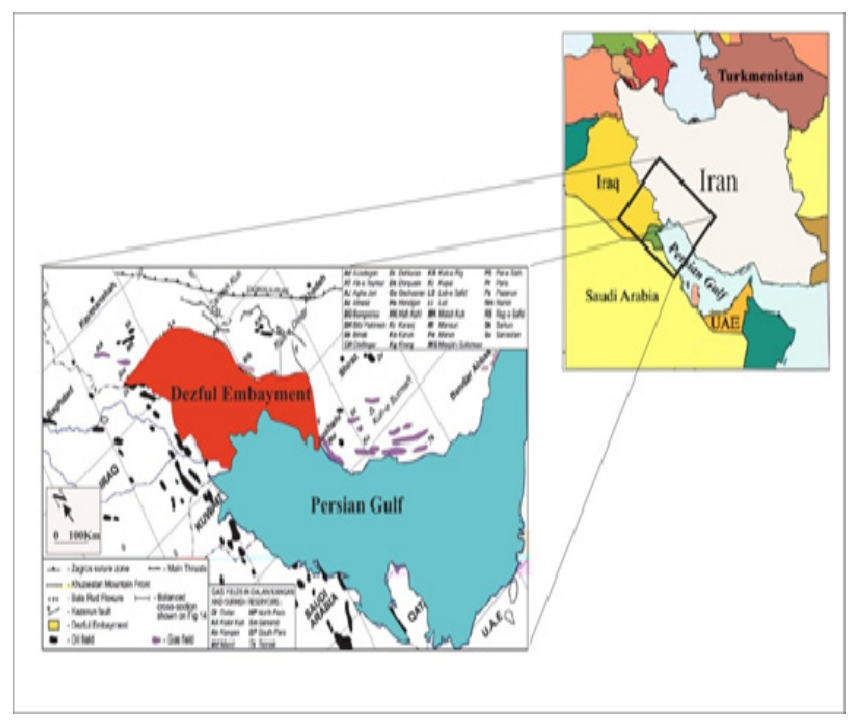

Fig. 1. Dezful Embayment location in the Zagros fold belt

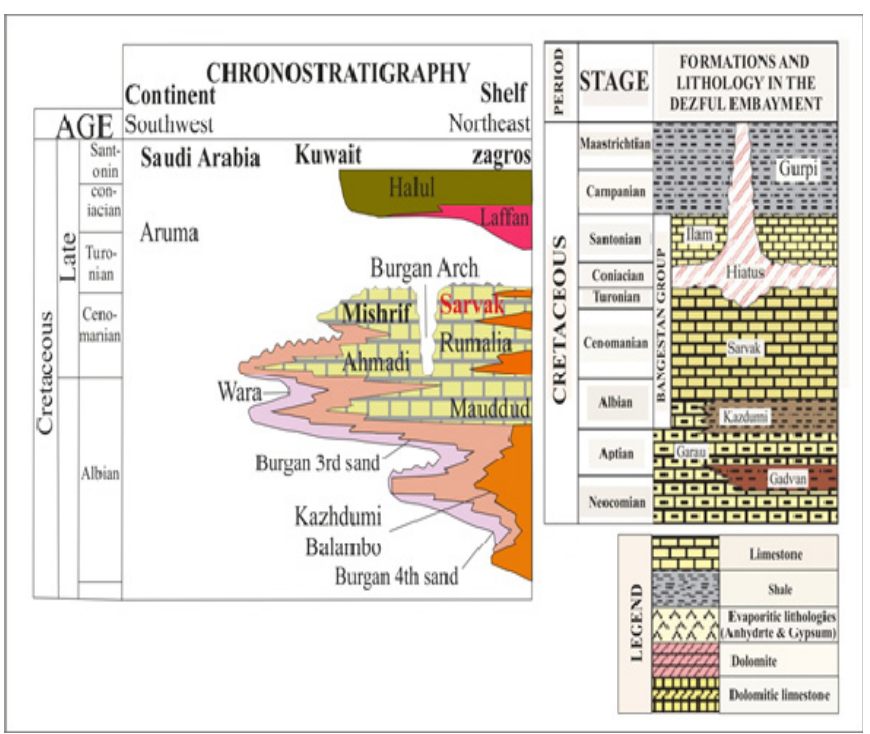

Fig. 2. A: Sratigraphy of Cretaceous in the Zagros region (SW Iran), Kuwait and Saudi Arabia. B: Stratigraphic location of Sarvak Formation in Dezful Embayment

To better assess reservoir distances according to the shale volume, the Sarvak Formation was divided to separate sections. Conventional petrophysical cross plots were used to determine the lithology. Water saturation was calculated using the Archie method and porosity by neutron graph, sonic and density. Also Neutron-Gama and water saturation-effective porosity cross plots were used to separate quality reservoir samples from poor quality samples. The studied logs in this survey include Notron (NPHI), Density (RHOB), Sonic (DT), Gama Ray (CGR, SGR), Resistivity (LLD, LLS, LL3, MLL), Caliper (CAL) and PEF logs.

\section{RESULTS AND DISCUSSION}

Petrophysical evaluation of a formation by well login can have an important role in quantitative and qualitative assessment of that formation. In the petrophysical evaluation of the Sarvak Formation using two wells (A and B), the following cases were studied:

\section{A. Lithological interpretation with cross-plots}

Identify the lithology is an important step on evaluation of reservoir properties and helps to separate reservoir zones from non-reservoir zones. In this study, formation lithology was identified using two methods.

\section{B. Neutron-Density Cross Plot}

In this cross plot three graph of limestone lithology, sand and dolomite are plotted (Figure 3). For identifying lithology just a plot of density against neutron is needed. The location of plotted points considering point distances from matrix lines shows the lithology percent [32]. This method shows the best porosity recognition among cross plots. As showed in Figure 3 major lithology of well A is limestone and little dolomite. Well B has the same lithology but with a different ratio 


\section{Neutron-Sonic Cross Plot}

In this cross plot, it is sufficient to plot DT (sonic) against neutron. Location of plotted point considering to distances of point from matrix lines shows the percent of lithology. Due to matrix effects on porosity, the individuation of curves is impressive [32]. Obtained results from this cross plot approximately confirm the lithology and porosity obtained from the Neutron-Density cross plot (Figure 4).

\section{Effective Porosity-Gama Cross Plot (NPHI-CGR)}

With this cross plot, reservoir intervals can be separated from shale intervals, at intervals of shale CGR and NPHI response to shale presence and as a result, plotted points appear as a linear graph, considering to this point which CGR only response to the shale and NPHI addition of response to shale presence, also response to saturated fluid. If clay percentage is low, plotted point are set out of the process of the linear graph [33]. The plotted points in the Sarvak Formation, in both A and B wells, show increased NPHI that is not matched with increased CGR and in fact the CGR is approximately linear which shows the low amount of shale and NPHI increase of porosity in this formation (Figure 5).

\section{E. Water saturation-Effective porosity Cross Plot}

In this cross plot, water saturation plotted against effective porosity is performed. These two parameters are inversely with each other. So, a section with low saturation shows good reservoir quality. By using this cross plot, it was determined that when saturation decreases, the effective porosity increases and reservoir quality rises (Figure 6).

\section{F. Calculating shale volume}

One of the most important considerations in the evaluation of formation is the identification of shale percentage, as it is rather important to the correct calculate formation porosity and fluid saturation. Several log are used, including gama, neutron and resistance, separately or combined [34]. The CGR log was used in this study. If the amount of shale is less than $10 \%$ then we have a "clear stone" whereas between 33-10 we have a "shaley" and over 33\% a "shale" [34]. Average calculated shale volume of this formation in wells A and B respectively is 2.9 and 7.04. Thus, the Sarvak Formation is clean limestone without clay and shows increased shale volume in well B.

\section{G. Calculating porosity}

Stored, porosity is also an important parameter in petrophysical evaluation. Porosity is calculable with neutron, sonic and density graphs. In well A, most porosity is related to section 6 whereas in well $\mathrm{B}$ most porosity is related to section 2 .

\section{H. Calculating water saturation}

Fluid saturation is the ratio of fluid volume in rocks (into volume empty spaces). This parameter thas no dimension and is expressed as a percentage. To calculate the water saturation in zone that is not impregnated to reservoir (to drilling mud), is performed with the Archie formula [35]:

$$
\mathrm{Sw}=\left(\mathrm{a} / \mathrm{phi}^{\wedge} \mathrm{m}^{*} \mathrm{Rw} / \mathrm{Rt}\right)^{\wedge} 1 / \mathrm{n}
$$

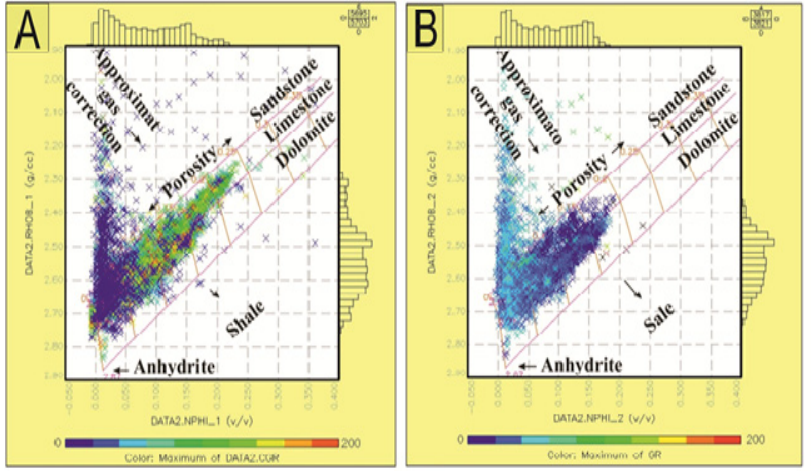

Fig. 3. Neutron-Density Cross Plot For wells A and B
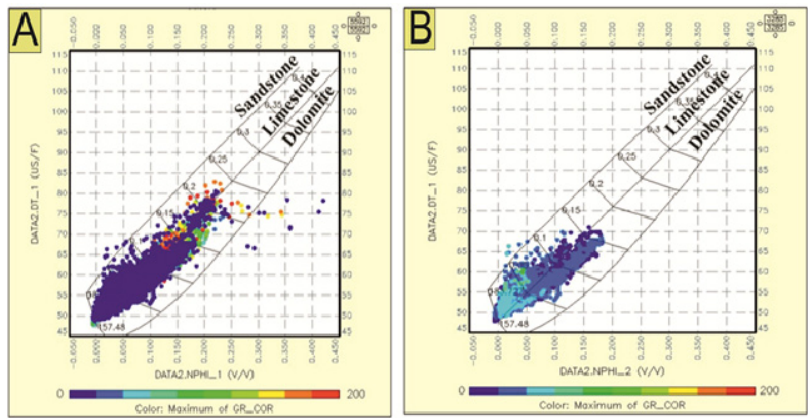

Fig. 4. Neutron-Sonic Cross Plot for wells A and B
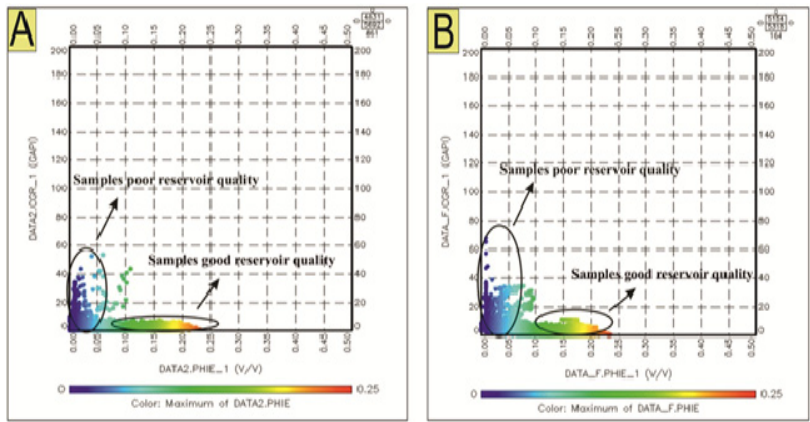

Fig. 5. Effective Porosity-Gama Cross Plot for wells A and B
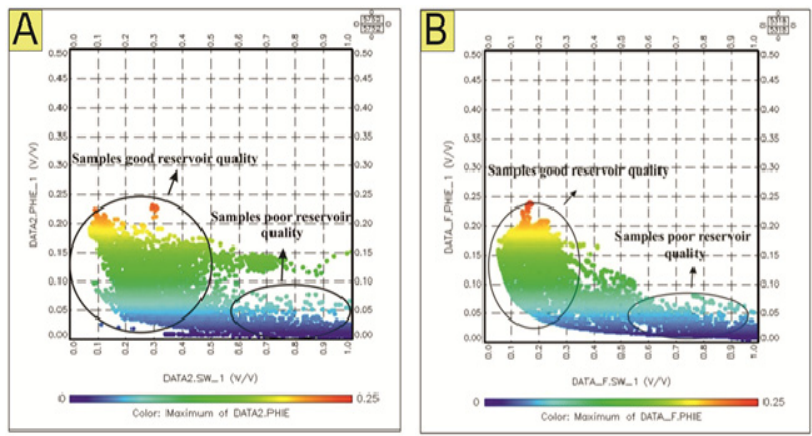

Fig. 6. Water saturation-Effective porosity Cross Plot for wells A and B

where $\mathrm{Sw}$ is the water saturation, a is the tortuosity coefficient, phi is the porosity, $\mathrm{m}$ is the cementation ability, $\mathrm{Rw}$ is the 
resistance of water formation in formation temperature, Rt is the true formation resistance and $\mathrm{n}$ is the saturation power that changes from 1.8 to 2.5 , with 2 usually considered. In Table I the average saturation of each zone is showed. The largest saturation for the Sarvak Formation is found in section 1 of Well A (84.5\%) and in section 1 of well B (77.5\%).

TABLE I. RESULTS OF PETROPHYSICAL EVALUATION IN WELLS A AND B

\begin{tabular}{|c|c|c|c|c|c|}
\hline WELL & INTERVAL & NET & PHIE & SW & VSH \\
\hline & $M E T E R S$ & $M E T E R S$ & $\%$ & $\%$ & $A P I$ \\
\hline A & 1A & 50 & 1.2 & 84.5 & 2.28 \\
\hline A & 2A & 210 & 3.2 & 55.4 & 2.21 \\
\hline A & 3A & 120 & 3.8 & 67 & 6.26 \\
\hline A & 4A & 132 & 9.2 & 28.3 & 2.12 \\
\hline A & 5A & 48 & 5.2 & 53 & 2.49 \\
\hline A & 6A & 150 & 9.4 & 52.6 & 2.41 \\
\hline B & 1B & 45 & 3.2 & 77.5 & 13.91 \\
\hline B & 2B & 210 & 5.5 & 58.5 & 4.96 \\
\hline B & 3B & 110 & 1.3 & 62.8 & 7.76 \\
\hline B & 4B & 130 & 13.8 & 19.5 & 4.15 \\
\hline B & 5B & 60 & 1.6 & 76 & 6.52 \\
\hline B & 6B & 105 & 12.2 & 25.7 & 4.98 \\
\hline
\end{tabular}

\section{CONCLUSION}

The key conclusions of this work are as follows:

- Petrophysical evaluation of well A: the Sarvak Formation in this well composes from mainly limestone and little dolomite and shale. Mentioned formation in this well has 710 meters thickness and is divided into 6 sections. The average formation effective porosity in this well is $4.6 \%$, the average shale volume 2.96 and the average water saturation is $56.8 \%$. Section 4 shows the best petrophysical parameters and it is the best section of this formation in terms of reservoir quality, followed by sections 6 and 2 respectively. Section 1 has the weakest petrophysical parameters and is the weakest, in terms of reservoir quality, section of this formation.

- Petrophysical parameters of well B: the Sarvak Formation in this well composes mainly from limestone and little shale and dolomite. The thickness is 660 meters and is divided to 6 section. The average porosity is $6.2 \%$, the average shale volume is 7.04 and the average water saturation is $53.2 \%$. Section 4 shows the best petrophysical parameters and reservoir quality and section 5 and 1 shows the weakest petrophysical parameters and thus a very low reservoir quality.

- The comparison of wells A and B shows that the major lithology in both wells is limestone and traces of shale and dolomite. Low shale volume is shown to be an important controlling factor regarding reservoir quality.

\section{REFERENCES}

[1] P. R. Sharland, R. Archer, D. M. Casey, R. B. Davies, S. H. Hall, A. P. Heward, A. D. Horbury, M. D. Simmons, Arabian plate sequence stratigraphy, GeoArabia Special Publication, Gulf PetroLink, Manama, Bahrain, 2001

[2] D. Tiab, Advances in Petrophysics, Flow Units, Lecture Notes \& Manual, University of Okhahoma, Vol. 8. 2010
[3] J. Hearst, P. Nelson, F. L. Paillet, Well logging for physical properties, 2nd edition, Joh Wiley \& Sons Ltd, 2000

[4] B. A. Al-Baldawi, "Petrophysical evaluation study of Khasib Formation in Amara oil field, South Eastern Iraq", Arabian Journal of Geosciences, Vol. 8, No. 4, pp. 2051-2059, 2015

[5] E. S. El-Din, M. A. Mesbah, M. A. Kassab, I. F. Mohamed, B. A. Cheadle, M. A. Teama, "Assessment of petrophysical parameters of clastics using well logs: The Upper Miocene in El-Wastani gas field, onshore Nile Delta, Egypt", Journal of Petroleum Exploration and Development, Vol. 40, No. 4, pp. 488-494, 2013

[6] A. A. Omran, N. M. Alareeq, "Log-derived Petrophysical Characteristics and Oil Potentiality of The Upper Qishn Clastic Member Masila Basin Yemen", Arabian Journal of Geosciences, Vol. 7, No. 5, pp. 1733-174, 20148

[7] A. M. Hassan, W. M. Mabrouk, K. M. Farhoud, "Petrophysical analysis for Ammonite-1 well, Farafra Area, Western Desert", Arabian Journal of Geosciences, Vol. 7, No. 12, pp. 5107-5125, 2014

[8] H. Al-Mohammad, R. Abdul, "Depositional Environment and Petrophysical Properties Study of Mishrif Formation in Tuba Oilfield, Southern Iraq", Journal of Basrah Researches Sciences, Vol 38. No.1A, pp. 25-50, 2012

[9] M. A. Alavi, "Structures of the Zagros Fold-Thrust Belt in Iran", American Journal of Science, Vol. 307, pp. 1064-1095, 2007

[10] M. Talebian, J. Jackson, "Offset on the Main Recent Fault of NW Iran and Implication for the Late Cenozoic Tectonics of the Arabia-Eurasia Collision Zone", Geophysical Journal International, Vol. 150, pp. 422439, 2002

[11] A. Bahroudi, H. A. Koyi, "Tectono-Sedimentary Framework of the Gachsaran Formation in the Zagros Foreland Basin", Marine and Petroleum Geology, Vol. 21, pp. 1295-1310, 2004

[12] M. Alavi, "Regional Stratigraphy of the Zagros Fold-Thrust Belt of Iran and Its Proforeland Evolution", American Journal of Science, Vol. 304, pp. 1-13, 2004

[13] G. Miliaresis, P. Iliopoulou,"Clustering of zagros rangs from the globe DEM representation", International Journal of Applied Earth Observation and Geoinformation, Vol. 5, No. 1, pp. 17-28, 2004

[14] M. L. Bordenave, J. A. Hegre, "The influence of tectonics on the entrapment Geology, of oil in the Dezful Embayment, Zagros Foldbelt, Iran", Journal of Petroleum Geology, Vol. 28, No. 4, pp. 339-368, 2005

[15] A. Setudehnia, "The Mesozoic sequence in southwest Iran and adjacent areas", Journal of Petroleum Geology, Vol. 1, pp. 3-42, 1978

[16] A. S. Alsharhan, A. E. M. Nairn, "A review of the Cretaceous formations in the Arabian Peninsula and Gulf: Part I, Lower Cretaceous (Thamama Group), stratigraphy and paleogeography", Journal of Petroleum Geology, Vol. 9, pp. 365-392, 1986

[17] A. Ghabeishavi, H. Vaziri-Moghaddam, A. Taheri, "Facies distribution and sequence stratigraphy of the Coniacian-Santonian succession of the Bangestan palaeo-high in the Bangestan anticline, SW Iran", Facies, Vol. 55, pp. 243-257, 2009

[18] A. Ghabeishavi, H. Vaziri-Moghaddam, A. Taheri, F. Taati, "Microfacies and depositional environment of the Cenomanian of the Bangestan anticline, SW Iran”, J. Asian Earth Sci., Vol. 37, pp. 275285,2010

[19] C. Hollis, "Diagenetic controls on reservoir properties of carbonate successions within the Albian-Turonian of the Arabian Plate", Petroleum Geoscience, Vol. 17, No. 3, pp. 223-241, 2011

[20] F. Lapponi, G. Casini, I. Sharp, W. Blendinger, N. Fernandez, I. Romaire, D. Hunt, "From outcrop to 3D modelling: a case study of a dolomitized carbonate reservoir, Zagros Mountains, Iran", Petroleum Geoscience, Vol. 17, pp. 283-307, 2011

[21] R. J. Murris, "Middle East: Stratigraphic evolution and oil habitat" AAPG Bulletin, Vol. 64, pp. 597-618, 1980

[22] W. Koop, R. Stoneley, "Subsidence History of the Middle East Zagros Basin, Permian to Recent", Philosophical Transactions of the Royal Society A, Vol. A305, pp. 149-168, 1982

[23] F. S. P. Van Buchem, P. Razin, P. W. Homewood, W. H. Oterdoom, J. Philip, "High-resolution sequence stratigraphy of the Natih formation 
(Cenomanian/Turonian) in northern Oman: distribution of source rocks and reservoir facies", GeoArabia, Vol. 1, pp. 65-91, 1996

[24] F. S. P.Van Buchem, B. Pittet, H. Hillgartner, J. Grotsch., A. Al Mansouri, I. M. Billing, H. Droste, W. H. Oterdoom, M. Van Steenwinkel "High resolution sequence stratigraphic architecture of Barremian/Aptian carbonate systems in Northern Oman", GeoArabia, Vol. 7, pp. 461-500, 2002

[25] A. Taghavi, A. Mork, M. Emadi, "Sequence stratigraphically controlled diagenesis governs reservoir quality in the carbonate Dehluran field, SW Iran", Petroleum Geoscience, Vol. 12, pp. 115-126, 2006

[26] B. Beiranvand, A. Ahmadi, M. Sharafodin, "Mapping and classifying flow units in the upper part of the mid-Cretaceous Sarvak formation (Western Dezful Embayment, SW Iran) based on a determination of the reservoir types", Journal of Petroleum Geology, Vol. 30, pp. 357-373, 2007

[27] E. Hajikazemi, I. Al-Aasm, M. Coniglio, "Subaerial exposure and meteoric diagenesis of the Cenomanian-Turonian upper Sarvak formation, southwestern Iran", Geological Society, London, Special Publications, Vol. 330, pp. 253-272, 2010

[28] H. Rahimpour-Bonab, H. Mehrabi, A. Enayati-Bidgoli, M. Omidvar, "Coupled imprints of tropical climate and recurring emergence on reservoir evolution of a mid-Cretaceous carbonate ramp, Zagros Basin, SW Iran”, Cretaceous Research, Vol. 37, pp. 15-34, 2012
[29] F. Ghazban, Petroleum geology of the PersianGulf, Joint publication of Tehran University Press and National Iranian Oil Company, Tehran, 2007

[30] E. Hajikazemi, I. Al-Aasm, M. Coniglio, "Chemostratigraphy of Cenomanian-Turonian carbonates of the Sarvak Formation, southern Iran", Journal of Petroleum Geology, Vol. 35, pp. 187-206, 2012

[31] H. Rahimpour-Bonab, H. Mehrabi, A. Navidtalab, E. Izadi-Mazidi, "Flow unit distribution and reservoir modeling in Cretaceous carbonates of the Sarvak Formation, Abteymour oilfield, Dezful Embayment, SW Iran, Journal of Petroleum Geology, Vol. 35, No. 3, pp. 213-236, 2012

[32] M. R. Rezaee, A. Chehrazi, Principles of interpretation well logs, Tehran University, 2006 [in farsi]

[33] R. M. Batman, "Open-hole log analysis and formation evaluation", International Human Resources, Vol. 28, No. 4, pp. 339-368, 1985

[34] M. R. Kamali, N. M. Lemon, S. N. Apark,'Porosity Generation and Reservoir Potential of Ouldburra Formation Carbonates, Officer Basin, South Australia", APEA Journal, Vol. 35, pp. 106-120,2003

[35] G. E. Archie, "The electrical resistivity $\log$ as an aid in determining somereservoir characteristics", Petroleum Technology, Vol. 5, pp. 5462,1942 